\title{
Application interactive methods and technologies of teaching chemistry
}

\author{
${ }^{1}$ Department of Teaching and Didactics of Chemistry, Faculty of Science, Charles University, Prague, Czech Republic, E-mail: \\ sadastayer@mail.ru
}

\begin{abstract}
:
Currently, chemistry education solves problems related to the definition of new values in order to improve the quality of education, personal development of the pupils, and problems of the teaching strategies that will stimulate the interest and commitment of the students for the natural sciences. The emphasis is on interactive teaching, using the subject matter in practice with ICT. Therefore, our goal is to create and verify an interactive chemistry course for lower secondary schools based on the characteristics of interactive, ICT-connected education and more interesting presentation of the subject matter. The first stage of our work consisted of an analysis of previous studies to establish the theoretical foundations on which to the base the use of ICT. Next, we have presented some of the developed methodological options, which illustrate the ability to use interactive methods. In the second stage, according to the different interactive chemistry programs and analysis of curriculum of the chemistry subject in the Czech Republic and Kazakhstan, we developed interactive teaching materials for chemistry lessons with interesting embedded content for lower secondary schools. In the next stage, all prepared materials will be verified and eventually adapted into the final form for use in chemistry teaching.

Keywords: interactive course, interactive lecture, lower secondary school, teaching chemistry
\end{abstract}

JEL classification: C32, C51, E32

DOI: $10.1515 /$ cti-2018-0031

\section{Introduction}

The problem of activation of mental activity, the development of self-reliance and creativity of students was and remains one of the topical problems of science. Universities, schools and governments spent large sums of money to build a sufficient infrastructure, to develop multi-media-based learning materials, and to equip students with the necessary computers (Ndibalema, 2014; Pelgrum, 2001). From the origin, the implementation of ICT in education was to transform the teaching and the learning process from the traditional instructional teacher-centered endeavour to a learner-centred approach with active participation of the learner coach (Voogt, 2008; Voogt \& Pelgrum, 2005).

However, the effectiveness of ICT assisted learning is very much dependent on the ability of teachers to use the tools appropriately (Voogt, 2010; Voogt, Fisser, Pareja Roblin, Tondeur, \& van Braak, 2013).

Carlson and Gaido (2002) insisted that the process of investing in ICT tools and resources without adequately financing teacher professional development as well will lead to a wasteful scenario as teachers will not be able to use these instruments and resources in the way they were intended.

Koc (2005) stated that the use of ICT facilitates enable students to share, communicate and work collaboratively at any time and everywhere. For example, technologies such as interactive visualizations, text-to-speech tools, and computer simulations can provide multimodal representations of information, which supports students' understanding of academic language in specific context and visualization of complex scientific concepts and processes (Ardac \& Akaygun, 2005; Barak \& Dori, 2005; Bell \& Trundle, 2008).

In 2005, a national survey in England found that nearly $49 \%$ of primary teachers had applied ICT in primary schools, $77 \%$ of math teachers, $67 \%$ of science teachers and $49 \%$ of english teachers said they had applied ICTs in secondary schools (Becta, 2005). While such large-scale adoption is very much a UK phenomenon, there is increasing interest in the potential of this technology worldwide (Bell, 2002; Hodge \& Anderson, 2007; Kent, 2004).

In a pilot program conducted by an interactive technology provider measuring the impact of interactive technology on college marketing students, they found the following: $87 \%$ of students reported they were more likely to attend class, $72 \%$ of students reported they were more likely to participate, $61 \%$ of students reported 
they were more focused on the lecture, $70 \%$ of students reported they improved their understanding of specific concepts, and $63 \%$ of students reported that class was more fun (Anonymous , 2006).

Eastman (2007) describes using interactive technology for opinion questions to participate, and for multiple choice questions to measure the students' knowledge of the material and determine if the class was ready to move on to the next topic.

Glassett and Schrum (2009) describe this use of interactive technology as transforming learning routines, which includes accessing advanced learning resources and content, igniting cognitive processes that enhance learning (e.g. active inquiry vs. memorization), and changing teacher roles from delivery of content to facilitator or learning coach.

According to Gómez-Galán (2017), the reality in which we live allows us to use interactive technologies, such as the tablet or the smartphone, to favour the development of digital competence. In this same line, the Horizon Report (2017) indicates that the main technological trends in education for the next few years are Mobile Learning, Social Networks; Online Learning, BYOD, Hybrid and Collaborative; Flipped Classroom, Gamification, Virtual Reality.

Curto Prieto, Orcos Palma, Blázquez Tobías, and León (2019) study shows the level of satisfaction towards the use of the application Kahoot, in terms of learning achievement, carried out by students of second, third and fourth year of secondary education, between the ages of 12 and 16 years, in the subjects of mathematics, biology and geology and physics and chemistry. Kahoot is an excellent didactic tool to carry out different activities in the classroom, contributing to the increase of students' participation and improving the existing relationship among different members of the group (Carrera \& Álvarez, 2015; Zarzycka, 2014).

Since the implementation of ICT in Kazakh schools, there remains a huge gap in the integration of ICT in the classrooms. There have been few studies in this field of ICT in Kazakhstan, and most of the studies have focused on the implementation of ICT. Since the implementation ICT in Kazakh schools, there have not been few studies that explore how teachers use these tools in transmitting knowledge to the students and the impact that the use of ICT has brought to schools (Sadykov, 2016).

\section{Different interactive chemistry programs in the world}

The PhET Interactive Simulations project (2002) at the University of Colorado Boulder creates free interactive math and science simulations through an intuitive, game-like environment where students learn through exploration and discovery (link: https://phet. colorado.edu/en/).

Top universities like Harvard, MIT and the University of Adelaide to provide paid courses in biochemistry, electrochemistry, organic chemistry, alternative fuels (link: https://www.edx. org/learn/chemistry).

At the Virginia site (2016) allowed students to use their mobile devices in class to look up and share information during class discussions, which facilitated engaged learning (link: www.doe.virginia.gov).

Waterloo launched the Open-Science website (2017) to provide free online lessons in general chemistry, covering topics from the Canadian $11^{\text {th }}$ and $12^{\text {th }}$ grade curricula. Each lesson is designed to work as a stand-alone topic and contains several interactive elements to help students learn (link: https://open.science.uwaterloo.ca/7).

Virtual Kids Lab (2017) this new platform in Japan offers a variety of interactive experiments online, to allow children aged 10-15 years to discover the world of chemistry through simple and safe experiments (link: www.basf.com).

This Open Educational Resource (OER) textbook (2018) has been written specifically for students as a reputable source for them to obtain information aligned to the Utah Chemistry Standards. Every year, the book will be revised using teacher feedback and with new objectives to improve the book (link: https://www.uen.org/core/core.do?courseNum=3620).

Czech Republic has a variety of interactive programs for teaching chemistry, but we do not use them too much in chemistry lessons. The main problem for the new technology introduced in education are the fear and restlessness of the teacher. The second reason for the small use of didactic software in the teaching of chemistry may be its inappropriate content or form (Chroustová, 2017).

Among the freely available interactive programs and internet portals in chemistry in the Czech Republic, we can note, for example, Faculty of Science, Charles University in Prague (link: http://studiumchemie.cz). The portal aim to be an electronic guide to chemistry suitable for studying in lower and higher secondary school.

We would also like to note that there is no universal chemistry course, which could be used in all stages of the chemistry lesson: warm-up, introduction, presentation, practice, evaluation.

Therefore, our goal is to create and verify an interactive chemistry course for lower secondary schools based on the characteristics of interactive, ICT-connected education and more interesting subject matter. 


\section{The main characteristics of the interactive course "Chemistry"}

The starting point for creation of an interactive chemistry course for the ISCED 2 (lower secondary education) level was a thorough analysis of contents and methods of the current chemistry subject curriculum at this level in the Czech Republic and Kazakhstan, and research into the possibility of innovation of the subject matter and interactive teaching.

The reasons for comparing the curriculum of these two countries are similar structure and fundamental educational reform. Educational reform in the Kazakhstan was in accordance with new additions in curriculum SCES (545/2017 of the approval of standard curricula on general educational subjects, elective courses for general education organizations), which were published on 23 September 2017. SCES (State compulsory educational standard) of Kazakhstan defines the general objectives of public education and basic competencies for the overall development of the student's personality. It also defines general content of education, which is compulsory for all schools in Kazakhstan (Decree № 4 of the Republic of Kazakhstan, 2017). For comparison were used in the Czech Republic curriculum RVP ZV (General educational programme for lower-secondary schools) with all the additions that were added in 2016 (Rámcový vzdělávací program pro základní vzdělávání, 2016). The structure of the chemistry curriculum in the Czech and Republic of Kazakhstan curriculum are shown in the Table 1:

Table 1: The structure of the chemistry curriculum in the Czech Republic and Kazakhstan curriculum RVP ZV and SCES at the ISCED 2 (lower secondary education).

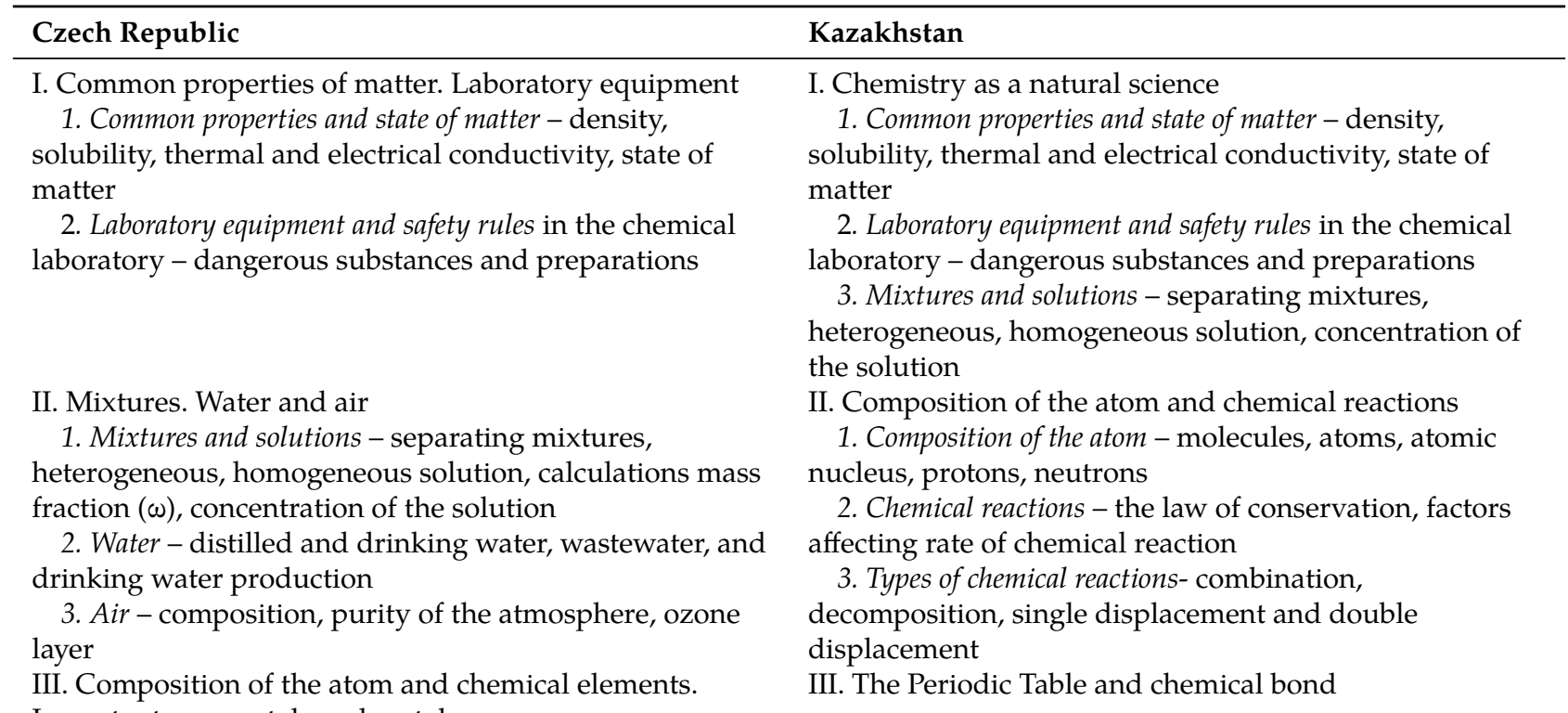

1. Composition of the atom - molecules, atoms, atomic
Important non-metals and metals nucleus, protons, neutrons

2. The Periodic Table - group of elements and their properties, name, symbols

3. Chemical compounds - types of chemical bonds

4. Important metals $-\mathrm{Na}, \mathrm{K}, \mathrm{Ca}, \mathrm{Mg}, \mathrm{Al}, \mathrm{Cu}, \mathrm{Pb}, \mathrm{Au}$

5. Important non-metals - N, P, C, Si, S, O, Cl, I

IV. Chemical reactions

1. Chemical reactions - the law of conservation of mass, Avogadro number, molar mass

2. Types of reactions - combination, decomposition, single displacement and double displacement

3. Factors affecting rate of chemical reaction

V. Inorganic compounds

1. Oxides - properties, classification of oxides

2. Acids and Bases - acidity or alkalinity of a solution:

properties, formulas, names and applications of acids and bases

3. Salts - the naming of salts, chemical properties VI. Organic compounds

1. The Periodic Table - group of elements and their properties, name, symbols

2. Chemical compounds - types of chemical bonds

IV. Inorganic compounds. Air and water

1. Oxides - properties, classification of oxides

2. Air - structure and properties

3. Acids and Bases - properties, formulas, names and applications of acids and bases

4. Salts - the naming of salts, chemical properties

5. Water - structure and properties

V. Chemistry and society

1. Chemistry and agriculture - detergents, pesticides and insecticides

2. Chemistry and human health - drugs and addictive substances

3. Plastics and synthetic fibbers - properties, use, disposal VI. Acidity or Alkalinity of a solution 
1. Hydrocarbons - preparation, chemical properties of alkanes, alkenes, alkyne

2. Fuels - oil, coal, natural gas

3. Derivatives of hydrocarbons - alcohols and carboxylic acids

4. Natural substances - sources, properties and examples of functions of proteins, fats, carbohydrates and vitamins in the human body

VII. Chemistry and society

1. Chemistry and agriculture - detergents, pesticides and insecticides

2. Chemistry and human health - drugs and addictive substances

3. Plastics and synthetic fibbers - properties, use, disposal
1. Acids and Bases - acidity or alkalinity of a solution: properties, formulas of acids and bases, mechanism of electrolytic dissociation, qualitative reactions

VII. Important non-metals and metals

1. Important metals - properties of $\mathrm{Na}, \mathrm{K}, \mathrm{Ca}, \mathrm{Mg}, \mathrm{Al}$, $\mathrm{Cu}, \mathrm{Pb}, \mathrm{Au}$ $\mathrm{Cl}, \mathrm{I}$

. Important non-metals - properties of N, P, C, Si, S, O,

VI. Organic compounds

1. Hydrocarbons - preparation, chemical properties of alkanes, alkenes, alkyne

2. Fuels - oil, coal, natural gas

3. Derivatives of hydrocarbons - alcohols and carboxylic acids

4. Natural substances - sources, properties and examples of functions of proteins, fats, carbohydrates and vitamins in the human body

The educational field of chemistry for lower-secondary schools, as can be seen, the position of this field of education in comparative educational documents of the Czech Republic and Kazakhstan is equal, but just slightly different arrangement in chemical curricula.

Our interactive course is created according to the interests, opportunities and professional orientation for lower secondary schools students and will be used on the educational portal: http:/ /interactive-chemistry.ru.

The learning goals of this course are:

- understand the causal relationships between composition, structure, properties and behaviour of substances;

- correct usage of chemical terminology, symbols of chemical elements, formulae of compounds and registration of chemical reactions;

- understand the connection between chemistry and an everyday life, technology and the society.

The course contains all themes of the current chemistry curriculum for lower secondary schools, and each theme makes the utmost use of connecting the subject matter with its practical application; the subject matter is acquired on the interactive basis (Sadykov \& Čtrnáctová, 2017).

Interactive learning is the ability to communicate or be in dialogue with someone (for example, a person) or with something (for example, a computer) (Maňák, 2003).

As Cerghit (2006) mentions "the interactive methods favor an interactive or interdependent group learning, students learn actively, taking place exchanges of knowledge, ideas, experiences, opinions, in order to jointly solve a work task".

The review of interactive methods of teaching and learning, possibilities and practical value of these methods in the educational system are considered in works Cerghit (2006), Wouters and Tabbers (2007), and Petruţa (2013).

The main advantages of interactive methods of teaching and learning are widely known:

- improving the quality of knowledge, because students are actively involved in the learning process;

- increasing the motivation of students in the educational process, acquisition of new material by not as passive listeners but as active participants;

- bringing flexibility and convenience in learning.

We have presented some of the developed methodological options, which illustrate the ability to use interactive lectures and innovated subject matter. 


\section{Interactive lecture}

Interactive lecture implies active involvement and participation by the audience so that students are no longer passive in the learning process. Learners can communicate with the lecturer, give him/her feedback, and can thus actively influence the teaching.

What prevents us from giving interactive lectures?

- Fear of losing control when giving an interactive lecture. They fear that if the class is allowed to participate actively and ask questions, the presenter will no longer be "in control", of either the students or the material.

- Fear of not covering all of the material. It is true that the "number of facts" need to be reduced in order for a lecture to become interactive (Yvonne \& Snell, 1999).

Interactive lectures with using different ICT tools actively involve students in the learning process and provide them information about their success (Interactive exercises, 2017). The use of ICT allows the teacher to create interactive tasks in a different of programs such as SMART Notebook, Active Inspire, Hot Potatoes 6, and Learningapps.org, such as the Kahoot game base system.

An example of interactive lesson on the topic Chemical bond and its properties

(http://interactive-chemistry.ru/mod/page/view.php?id=16) shows Figure 1.

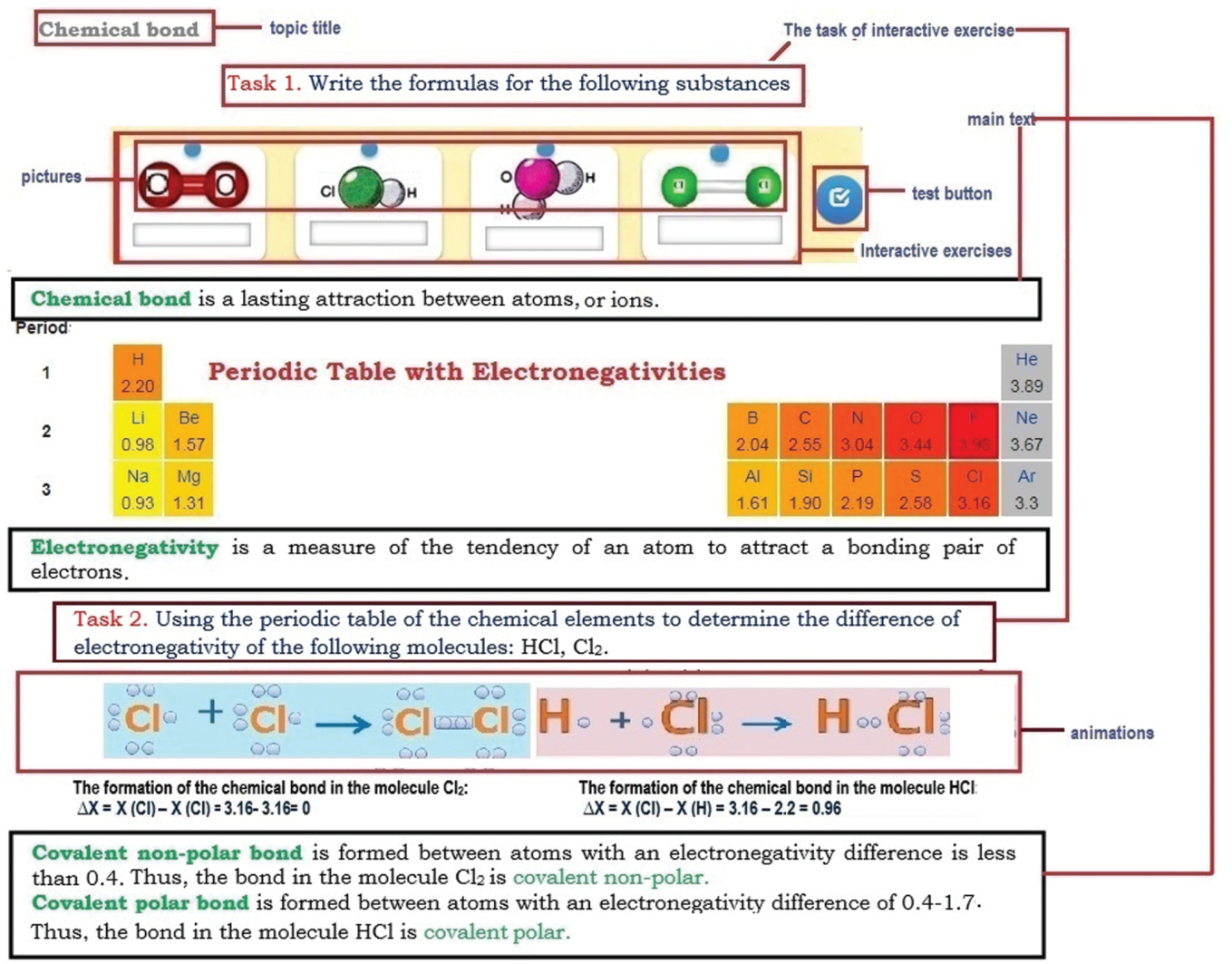

Figure 1: An example interactive lesson and exercise on the topic "Chemical bond".

The main purpose of the theme "chemical bond" to develop understanding of the different types of chemical bond. First, the lesson begins with interactive task № 1. «Write the formulas for the following substances». Knowledge of atomic structure helps students understand how atoms bond to each other to form compounds. After that, students can give an answer to the question: what is a chemical bond?

Second, the periodic table and the knowledge about chemical properties of an element helped students to find definition of electronegativity. According to the periodic table students practice interactive tasks № 2 .

Finally, animations of formation of chlorine and hydrochloric acid molecules to develop a deeper understanding of formation of the chemical bond and using a mathematical formula student to determine the type of chemical bond in these molecules. 


\section{Discussion and results}

We faced with two main problems when creating an interactive course.

The first issue is creation of an interactive course, which could be used in all stages of the chemistry lesson and actively involves students in educational process. Now there is a lot of interactive programs (shown above) and a significant shortage study about effective this program for lower-secondary schools. Similar approaches to solving this problem can be found only in Chiero and Beare (2010) and Tondeur, De Bruyne, Van Den Driessche, McKenney, and Zandvliet (2015). Their longitudinal study concluded that ratings for online preparation programs were consistently higher than for the more traditional program, suggesting that an online program can be as or more effective at preparing the lower-secondary students.

Our interactive course contains, in total, 14 thematic wholes, each of them containing 2-6 subthemes. All the themes are processed with respect to the practical application of the subject matter using the listed interactive education methods. The interactive materials from our course consists of text, pictures, animation, questions and tasks in interactive exercises, which are available in each stage of the lesson. The problems that came out more frequently in the field seem to be related to understanding the lesson's logic. This is, therefore, a sizeable teaching material, and its verification in practice will require quite demanding and extensive research.

The second issue related to question: «What ICT tools can we use in the teaching of interactive course?». Voogt (2010) concluded that one of the main reasons why teachers do not use ICT tools pedagogically in the classroom is the lack of time necessary to accomplish the pedagogical plan. However, this is the first time for students to use a variety of equipment, and some difficulties may occur. This is especially true when they had to do a project in groups and learned to present it using technologies in the classroom. This is probably due to the fact that students feel excited to be in a more technology-supported learning environment.

The use of the mobile phones not only changes the means by which students learn science, but also makes their learning more individualized. Students are able to learn at their own pace with the support of level appropriate online material (Delialioglu, 2005; Tuan, 2012). Additionally, the use of tablet computers can enable learning anywhere and at anytime. This creates a connection between home and school. This mobility also allowed teachers to place the students anywhere in the classroom instead of having them tied to a computer or an IW. Thanks to this mobility, students could move with the tablet computers and comment on the results (Blackwell, 2013).

We believe that combination of mobile phones and tablets allows several students to perform the activities at the same time, and this encouraged them to interact with each other. For instance, they discussed the correct answers of the activities, and they willingly helped their partners if they did not know the correct answer.

\section{Conclusions}

The first stage of our work in creating an interactive chemistry course for lower secondary schools was the analysis of content and methods of chemistry curriculum in the Czech Republic and Kazakhstan and the study of possible innovations of the subject matter and interactive education methods. We have presented some of the developed methodological options, which illustrate the ability to use interactive methods to increase cognitive activity of students and the effectiveness of the learning process using ICT.

In the second stage of our work, we developed interactive teaching and learning materials for chemistry lessons with embedded innovative content and interactive training methods for lower secondary schools. The course «Chemistry» that was created is, in its first version, available at the educational portal http:/ / interactivechemistry.ru. The great advantage is that the material is posted on the learning site, at the same time students can work in the school as well as at home. Interactive exercises give students feedback in the form of messages if it was a correct or incorrect answer (for some exercises), and an overall assessment (how many percentages of his work was successful). Now, in the next stage, our goal is to verify all prepared materials on selected schools in the Czech Republic and Kazakhstan and to eventually adapt them into the final form for use in chemistry teaching.

\section{References}

Anonymous (2006). Thomson Learning and Turning Technologies Pilot Reveals College Students More Likely to Attend Class and Interact With Instructor as a Result of Added Technology Resources. 
Ardac, D., \& Akaygun, S. (2005). Using static and dynamic visuals to represent chemical change at molecular level. International Journal of Science Education, 27(11), 1269-1298.

Barak, M., \& Dori, Y. J. (2005). Enhancing undergraduate students 'chemistry understanding through project-based learning in an it environment. Science Education, 89(1), 117-139.

Becta (2005). Evaluation of curriculum online: Emerging findings from the third survey of schools. Becta and the National Centre for Social Research, Coventry: BECTA. Retrieved August 20, 2018 from:http://www.becta.org.uk/ publications.

Bell, M. A. (2002). Why use an interactive whiteboard? A Baker's dozen reasons! Teachers' Net Gazette 3. Retrieved February 20, 2019 from: http://teachers.net/gazette/JANo2/.

Bell, R. L., \& Trundle, K. C. (2008). The use of a computer simulation to promote scientific conceptions of moon phases. Journal of Research in Science Teaching, 45(3), 346-372.

Blackwell, C. (2013). Teacher practices with mobile technology: Integrating tablet computers into the early childhood classroom. Journal of Educational Research, 7(4), 1-25.

Carlson, S., \& Gaido, C. (2002). Teacher Professional Development in the Use of Technology. Retrieved February 20, 2019, from http://www.ictinedtoolkit.org/usere/library/tech_for_ed_chapters/08.pdf.

Carrera, D. A., \& Álvarez, L. A. (2015). Sistemas de Respuesta en Aula de Libre Distribución para uso con Dispositivos Móviles. Actas V Encuentro Conferencias Chilenas en Tecnologías del Aprendizaje. Arica.

Cerghit, I. (2006). Metode de învăţământ. EdPolirom: Bucureşti, 4(4), 66-89.

Chiero, R., \& Beare, P. (2010). An evaluation of online versus campus-based teacher preparation programs. Merlot Journal of Online Learning and Teaching, 6, 4-11.

Chroustová, K. (2017). Akceptace a používání didaktického software učiteli vzhledem k metodám a organizačním formám výuky chemie (disertační práce). Univerzita Hradec Králové, Hradec Králové.

Curto Prieto, M., Orcos Palma, L., Blázquez Tobías, P. J., \& León, F. J. M. (2019). Student assessment of the use of kahoot in the learning process of science and mathematics. Education Sciences, 9, 55.

Decree № 4 of the Republic of Kazakhstan. 2017. Retrieved August 19, 2017, from web address: http://egov.kz/cms/ru/law/list/P1200001080.

Delialioglu, O. (2005). Student perceptions and readiness on using a mobile. Application for Vocabulary Acquisition, 1, 687-695.

Eastman, J. K. (2007). Enhancing classroom communication with interactive technology: How faculty can get started. College Teaching Methods \&Styles Journal, 3(1), 31-38.

Classett, K., \& Schrum, L. (2009). Teacher beliefs and student achievement in technology-rich classroom environments. International Journal of Technology in Teaching and Learning, 5(2), 138-153.

Gómez-Galán, J. (2017). Nuevos estilos de enseñanza en la era de la convergencia tecno-mediática: Hacia una educación holística e integral. International Journal of Educational Research, 8, 60-78.

Hodge, S., \& Anderson, B. (2007). Teaching and learning with an interactive whiteboard: A teacher's journey. Learning, Media and Technology, $32,100-118$.

Horizon Report (2017). Higher Education Edition. The New Media Consortium: Austin. Retrieved April 19, 2019, from: https://www.sconul.ac.uk/.../2017-nmc-horizon-report-he-EN.pdf.

Interactive exercises. 2017. Retrieved August 19, 2017, from: http://www.veskole.cz/clanky/interaktivni-cviceni-nebo-podklady-pro-vyukuzalezi-nam-na-kvalite.

Kent, P. (2004). E-teaching with interactive whiteboards. Practising Administrator, 2, 26-34.

Koc, M. (2005). Implications of learning theories for effective technology integration and preservice teacher training: A critical literature review. Journal of Turkish Science Education, 2(1), 2-18.

Maňák, J. (2003). Nárys didaktiky. 3. vyd. Brno: Masarykova univerzita.

Ndibalema, P. (2014). Teachers' Attitudes towards the Use of Information Communication Technology (ICT) as a Pedagogical Tool in Secondary Schools in Tanzania: The Case of Kondoa District. International Journal of Education and Research, 2(2), 1-16.

Pelgrum, W. J. (2001). Obstacles to the integration of ICT in education: Results from a worldwide educational assessment. Computers and Education, 37(2), 163-178.

Petruţa, G. P. (2013). Teacher's opinion on the use of interactive methods/techniques in lessons. In: Social and Behavioural Sciences, 1(1), 649653.

Rámcový vzdělávací program pro základní vzdělávání (2016). Retrieved January 19, 2017, from: www.nuv.cz/uploads/RVP_ZV_2016.pdf.

Sadykov, T. (2016). The history of the development of interactive technologies in Kazakhstan. Problems of Modern Science and Education, 1(43), 219-221.

Sadykov, T., \& Čtrnáctová, H. (2017). Současné interaktivní metody výuky chemie na úrovni ISED 2. In: Aktuálně problémy dizertačních prác v teórii prirodoveného vzdelávania. Trnava: Trnavská univerzita, 53-60.

Tondeur, J., De Bruyne, E., Van Den Driessche, M., McKenney, S., \& Zandvliet, D. (2015). The physical placement of classroom technology and its influences on educational practices. Cambridge Journal of Education, 45(4), 537-556.

Tuan, L. (2012). An empirical research into EFL learners' motivation. Theory and Practice in Language Studies, 2(3), 430-439.

Voogt, J. (2008). Satisfying Pedagogical Practices Using ICT. In: Pedagogy and ICT use in schools around the world, 1(2), 221-250.

Voogt, ]. (2010). Teacher factors associated with innovative curriculum goals and pedagogical practices: Differences between extensive and non-extensive ICT-using science teachers. Journal of Computer Assisted Learning, 26, 453-464.

Voogt, ]., \& Pelgrum, H. (2005). ICT and curriculum change. Interdisciplinary Journal on Humans in ICT Environments, 1(2), 157-175.

Voogt, J., Fisser, P., Pareja Roblin, N., Tondeur, J., \& van Braak, J. (2013). Technological pedagogical content knowledge-a review of the literature. Journal of Computer Assisted Learning, 29, 109-121.

Wouters, P. H., \& Tabbers, H. K. (2007). Interactivity in video-based models. Educational Psychology Review, 19(3), 327-342.

Yvonne, S., \& Snell, L. (1999). Interactive lecturing: Strategies for increasing participation in large group presentations. Medical Teacher, 21(1), 37-42.

Zarzycka, E. (2014). Kahoot it or not? Can games be motivating in learning grammar? Teaching English with Technology, 16, 17-36. 